\title{
Pengaruh Penambahan Tepung Daun Kemangi dalam Pakan Sebagai Imbuhan Pakan Terhadap Pertambahan Bobot Badan Kelinci Keturunan New Zealand White
}

\author{
Dyanovita Al Kurnia* dan Umar Faruk* \\ * Program Studi Peternakan Fakultas Peternakan Universitas Islam Lamongan \\ JI.Veteran No.53.A Lamongan
}

\begin{abstract}
Salah satu cara meningkatkan produktifitas kelinci adalah dengan pemberian pakan tambahan tepung daun kemangi sebagai imbuhan pakan. Kemangi diketahui memiliki multi efek farmakologis yaitu mampu menurunkan panas, antidisentri, menambah nafsu makan, memperbaiki saluran pencernaan, memiliki sifat khas tajam, menghangatkan dan dapat melancarkan peredaran darah (Sutarno dan Atmowidjojo, 2001).

Tujuan penelitian ini adalah untuk mengetahui pengaruh penambahan tepung daun kemangi sebagai imbuhan pakan terhadap pertambahan bobot badan kelinci peranakan New Zealand White.Penelitian ini dilaksanakan di Desa Primpen Kecamatan Bluluk Kabupaten Lamongan mulai tanggal 15 April 2016 sampai 14 Juni 2016. Materi yang digunakan adalah 16 ekor kelinci yang baru lepas sapeh sekitar umur 2 bulan dengan bobot badan $317 \pm 340$ dibagi dalam empat perlakuan empat ulangan, tiap ulangan terdiri dari satu ekor kelinci.

Ransum yang digunakan adalah rumput lapang dan kosentrat dengan perbadingan antar 35:65.Perlakuan yang diberikan adalah P0(35 rumput lapang dan 65 kosentrat), sebagai kontrol. P1 ( ransumkontrol $+2 \%$ tepung daun kemangi), P2 ( ransum kontrol + 4\% tepung daun kemangi), P3 ( ransum kontrol + 6\% tepung daun kemangi). Parameter yang diamati adalah pertambahan bobot badan.Data hasil penelitian dianalisis dengan analisis variasi berdasarkan Rancangan Acak Lengkap (RAL) pola searah, apabilah didapatkan hasil bebeda nyata diantara perlakuan maka dilanjutkan dengan uji Duncan (DMRT).

Hasil penelitian menunjukan bahwa rerata dari keempat macam perlakuan yaitu P0, P1, P2, dan P3 berturutturut untuk pertambahan bobot badan mingguan yaitu 136,187, 118,852, 273,006, 123,937. Hasil analisis variansi menunjukan bahwa pertambahan bobot badan dari keempat perlakuan adalah berbeda nyata.

Kesimpulan yang diperoleh dari penelitian ini adalah bahwa penggunaan tepung daun kemangi sebagai imbuhan pakan dengan level $6 \%$ dari total ransum mampu memberikan pengaruh terhadap pertambahan bobot badan kelinci New Zealand White.
\end{abstract}

\section{PENDAHULUAN}

\section{Latar Belakang Masalah}

Kelinci merupakan hewan herbivora non ruminansia yang sebagian besar keperluan pakannya dipenuhi dari hijauan. Menurut Ensminger (1991), imbangan pakan berupa hijauan dan konsentrat pada peternakan kelinci intensif adalah 50-60\% hijauan, 50-40\% konsentrat.

Ternak kelinci adalah salah satu komoditas ternak yang memiliki kualitas daging dengan struktur serat lebih halus dengan bentuk dan warna yang menyerupai daging ayam, dengan kandungan protein lebih tinggi di bandingkan dengan ternak sapi, domba, kambing dan babi.

Sarwono (2003), Menambahkan bahwa daging kelinci mengandung protein tinggi dan dapat diserap oleh tubuh sehinga dapat menimbulkan energi serta kandungan lemaknya sangat sedikit (rendah kolestrol). Kandungan nutrisi daging kelinci menurut Kastadisstra (1997), yaitu kalori 160 kkal, protein 21 persen, lemak 8 persen dan $\mathrm{Ca} 0,02$ persen.

Pakan merupakan salah satu faktor yang sangat penting bagi kelangsungan jalannya peternakan, mengingat bahwa pakan merupakan biaya terbesar yang di keluarkan oleh usaha peternakan.Pada pola pemeliharaan intensif biaya produksi peternakan terbesar berasal dari pakan yaitu sebesar $60-70 \%$.Oleh karena itu, upaya peningkatan efisiensi pakan atau menurunkan biaya pakan merupakan suatu keharusan (Murtisari, 2005).

Kemangi memiliki kandungan minyak atsiri yang mampu meningkatkan relaksasi usus halus sehingga menyerap zat-zat nutrisi untuk pertumbuhan optimum. Minyak atsiri dalam kemangi juga dapat menghambat bakteri penyebab diare sehingga proses pencernaan dan penyerapan zat-zat nutrisi menjadi lebih sempurna serta dapat memperbaiki saluran pencernaan (Nugroho, 1998).

Kemangi diketahui memiliki multi efek farmakologis yaitu mampu menurunkan panas, antidisentri, menambah nafsu makan, memperbaiki saluran pencernaan, memiliki sifat khas tajam, menghangatkan dan dapat melancarkan peredaran darah (Sutarno dan Atmowidjojo, 2001).

Penambahan tepung daun kemangi dalam ransum diharapkan dapat memperbaiki sistem pencernaan makanan dan penyerapan zat-zat makanan sehingga dapat meningkatkan nafsu makan. 


\section{MATERI DAN METODE PENELITIAN}

Penelitian pengaruh penambahan tepung daun kemangi sebagai imbuhan pakan terhadap pertambahan bobot badan kelinci peranakan New Zealand White dilakukan \pm 2 bulan pada bulan April sampai Juni. Penelitian ini dilakukan dalam dua tahap:

a. Tahap pertama yaitu 1 bulan persiapan pembuatan imbuhan pakan dan ransum.

b. Tahap kedua yaitu persiapan pengukuran berat badan selama 1 bulan yang dilakukan setiap satu minggu.

Materi yang digunakan dalam penelitian ini adalah tepung daun kemangi yang diberikan kepada kelinci jenis peranakan New Zealand White yang baru lepas sapih sekitar umur 2 bulan dengan bobot badan hidup rata-rata 317 - $340 \mathrm{gr}$ dengan jumlah anakan 16 ekor yang tidak dibedakan jenis kelaminnya (unsex).

Metode yang penelitian secara eksperimen. Dengan menggunakan rumus RAL (Mattjik dan Sumertajaya), 2002 adalah $: \mathbf{Y i j}=\mu+\mathbf{a} \mathbf{i}+\varepsilon \mathbf{i j}$

Keterangan :

Yij = Hasil pengamatan perlakuan ke-i

$\mathrm{M}=$ Nilai rataan umum perlakuan

$\mathrm{Ai}=$ Pengaruh perlakuan ke-i

Eij= Error (galat) ulangan ke-i dan perlakuan pemberian

I = Jenis pakan

$\mathrm{j} \quad=$ Ulangan $(\mathrm{j}=4)$

variabel yang diamati adalah Pertambahan bobot badan. PBBdihitung berdasarkan bobot badan awal dan bobot badan akhir selama penelitian yang dinyatakan dalam (gram/ekor/hari)

\section{PBB = bobot akhir - bobot bawal (g/ekor) Lama Penelitian}

Susunan perlakuan penelitian adalah sebagai berikut:

$\mathrm{P}_{0}$ : Hijauan $35 \%+$ Kosentrat $65 \%$ (R. kontrol)

$\mathrm{P}_{1}$ : Ransum kontrol $+2 \%$ tepung daun kemangi

$\mathrm{P}_{2}$ : Ransum kontrol $+4 \%$ tepung daun kemangi

$\mathrm{P}_{3}$ : Ransum kontrol $+6 \%$ tepung daun kemangi

\section{HASIL DAN PEMBAHASAN}

Hasil Sampel Proksimat Lengkap Pakan Kelinci dan imbuhan pakan tepung daun kemangi.

Tabel 5: Hasil Sampel Proksimat Lengkap Pakan Kelinci dan imbuhan pakan tepung daun kemangi.

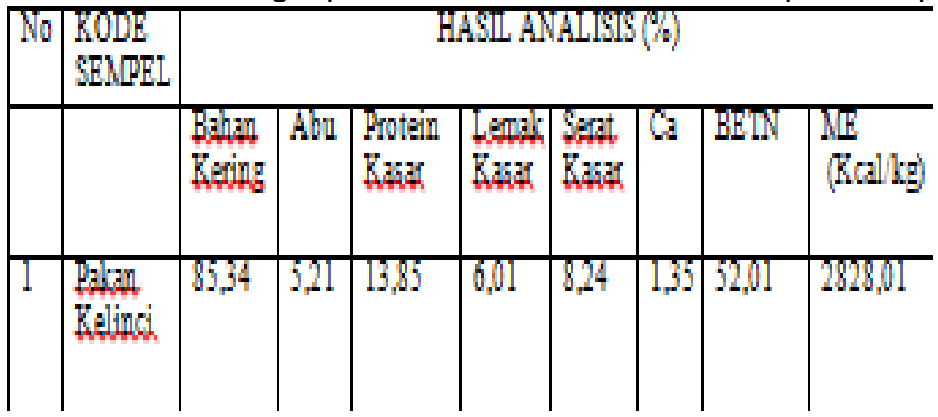

Sumber: Unit Pelayanan Pemeriksaan Laboratoris, konsultan Dan Pelatihan Airlangga 2016

Parakkasi (1999), menyatakan bahwa penambahan protein dalam ransum dapat meningkatkan pertambahan bobot badan sedangkan penambahan serat dalam ransum akan menurunkan bobot badan. Pakan kelinci membutuhkan nutrisi untuk memenuhi kebutuhan hidupnya, yaitu kebutuhan hidup pokok dan produksi (Siregar, 1994). Kebutuhan nutrisi dipenuhi dari ransum yang dimakan dan mampu dicerna ole hternak (Blakely dan Bade, 1992).

Kebutuhan hidup pokok adalah kebutuhan minimal yang harus dipenuhi, jika nutrisi yang dibutuhkan tidak tersedia dalam ransum, tubuh ternak akan membongkar cadangan energi (glikogen, lemakdan protein) tubuh untuk mempertahankan kelangsungan hidup (Tillman et al., 1998). Kebutuhan energi pada kelinci untuk pertumbuhan atau laktasi dan hidup pokok adalah 2500 dan $2100 \mathrm{Kcal} / \mathrm{kg}$ DE (NRC, 1977). 
Karbohidrat adalah sumber energi yang potensial pada kelinci (Ensminger et al.,1990). Karbohidrat ransum terbagi menjadi dua yaitu karbohidrat yang siap dicerna, seperti pati dan sukrosa, dan karbohidrat yang sulit dicerna yaitu selulosa dan hemiselulosa (Cheeke et al., 1982).

Seratkasar tidak sepenuhnya digunakan kelinci sebagai sumber energi, tetapi serat kasar adalah komponen yang penting terdapat dalam ransum kelinci. Serat kasar dicerna oleh bakteri yang terdapat dalam sekum dan kolon kelinci. Hasil fermentasi dalam sekum adalah VFA (Cheeke et al., 1982). Sarwono (2002) menyatakan bahwa kelinci tidak mampu mencerna serat kasar dengan baik dibanding ternak ruminansia, kemampuan mencerna serat kasarhanya $10 \%$.Serat kasar yang direkomendasikan NRC (1977).

Blakely dan Bade (1992) menyatakan bahwa kebutuhan protein pada fase pertumbuhan lebih tinggi daripada fase dewasa, karena protein tersebut selain digunakan untuk hidup pokok juga untuk pertumbuhan jaringan.

\section{Pertambahan Bobot Badan}

Tabel 4: Rerata Pertambahan Bobot Badan Kelinci Peranakan New Zealand White selama penelitian (g/ekor/minggu).

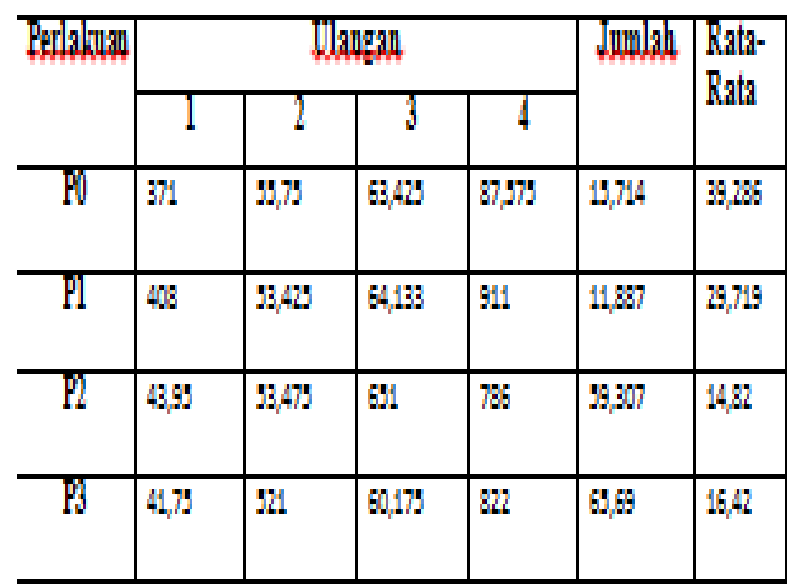

Sumber: Diolah dari data primer (2016)

Berdasarkan tabel diatas rerata pertambahan bobot badan mingguan didapatkan selama penelitian untuk masing-masing perlakuan P0, P1, P2, P3 berturut - turut yaitu : 136,187, 118,852, 273,006 dan 123,937 gram/ekor/minggu.

Pertambahan berat badan kelinci lokal yang ideal sebesar $4-21$ gram/ekor/hari (Sangare, et al., 1992). Analisis variansi menunjukkan hasil berbeda nyata $(\mathrm{P}<0,05)$ terhadap pertambahan bobot badan mingguan kelinci peranakan New Zealand White. Hal ini berarti bahwa pemberian tepung daun kemangi dengan level $6 \%$ dari total ransum berpengaruh terhadap pertambahan bobot badan mingguan.Sedangkan Hasil uji Duncan Multiple Ranger Test(DMRT) menunjukan bahwa perlakuan membuktikan adanya pengaruh terhadap pertambahan bobot badan kelinci akan tetapi tidak berbeda nyata antar perlakauan.

Pertambahan bobot badan mingguan diduga karena kandungan minyak atsiri dalam tepung kemangi cukup tersedia untuk dapat merangsang sekresi hormon insulin dari pancreas sehingga mampu merangsang sintesa protein dengan cepat. Menurut Maheswari (2002), ikatan kimia minyak atsiri memiliki badan keton, ditambahkan oleh Indah (2003) badan keton merupakan salah satu faktor dalam merangsang sekresi insulin dari pankreas, insulin akan berpengaruh pada hati dan otot dalam merangsang sintesa protein yang sangat penting sebagai salah satu faktor pertumbuhan ternak, selain itu jumlah dan kualitas zat makanan yang dikonsumsi berpengaruh nyata terhadap pertumbuhan ternak. Semakin tinggi konsumsi pakan maka pertumbuhan juga akan semakin baik, konsumsi pakan yang berbeda nyata juga menjadi salah satu penyebab pertambahan bobot badan mingguan berbeda nyata. Didukung oleh Mugiyono dan Karmada, (1989) bahwa kecepatan pertumbuhan ditentukan oleh jumlah zat makanan yang dikonsumsi atau mutu dan jumlah pakan yang dimakan.Ditambahkan oleh Soeparno (1994) bahwa nutrient berhubungan langsung dengan laju pertumbuhan serta komposisi tubuh ternak selama pertumbuhan. 


\section{KESIMPULAN DAN SARAN \\ Kesimpulan}

Kesimpulan yang diperoleh dari penelitian ini adalah bahwa pengunaan tepung daun kemangi sampai dengan level $6 \%$ dari total ransum mampu memberikan pengaruh terhadap pertambahan bobot badan kelinci peranakan New Zealand Whiteakan tetapi tidak berbeda nyata antar perlakuan.

\section{Saran}

Penambahan tepung daun kemangi dapat ditambahkan kedalam pakan kelinci dengan level $6 \%$ ke dalam ransum kelinci peranakan New Zealand White.Agar mendapatkan pertumbuhan kelinci dengan optimal.

\section{REFERENSI}

Chekee, P. R. 1987. Rabbit Feeding and Nutrition.Oregon State University. Corvalis, Oregon.

Ensminger, M. E., J. E. Oldfield \& W. W. Hineman. 1991. Feed and Nutrition (Formaly Feed and Nutrition Complete).2nd Edition.The Ensminger Publishing Company. California.

Indah, M., 2003.Mekanisme Kerja Hormon. www.library.us.u.ac.id/download/hormon-mutiara.pdf[17 juni 2008]. 20 juli 2016

Kartadisastra, H. R., 1997. Ternak Kelinci Teknologi Pasca Panen. Kanisius. Yogyakarta.

Murtisari, T., 2005. Pemanfaatan Limbah Pertanian Sebagai Pakan UntukMenunjang Agribisnis Kelinci. Dalam :Lokakarya Nasional Potensi danPeluang Pengembangan Usaha Kelinci. Bandung : 30 September 2005.Bogor: Pusat Penelitian dan Pengembangan Peternakan hal. 41-54. Diakses pada tanggal 5 april 2007. Di ambil pada tanggal 01 April 2016. 17.00 WIB.

National Reseach Council. 1977. Nutrient Requirement of Rabbit.National Academic of Science, Washington.

Parakkasi, A. 1999. Ilmu Nutrisi dan Makanan Ternak Ruminan. Universitas Indonesia Press, Jakarta.

Sangare, N., O. M. Arif, S. Moin and F .Dahlan, 1992.Breed Differences Rabbit.

Sarwono, B., 2003. Kelinci Potong dan Hias. AgroMedia Pustaka. Jakarta.

Sarwono, B., 2002. Kelinci Potong dan Hias. AgroMedia Pustaka. Jakarta.

Siregar, 1994, Kebutuhan Nutrisi Ransum Kelinci, Gadjah Mada University Press, Yogyakarta.

Soeparman, 1994, IImu dan Teknologi Daging, Gadjah Mada Universitas Press. Yogyakarta

Tilman, A, D., H. Hartadi, S. Reksohadiprojo, S. Prawirokusumo dan S. Lebdosoekojo, 1998. IImu Makanan Ternak Dasar. Gadjah Mada University Press, Yogyakarta. 